\title{
FRINGILLA ELEGANS.
}

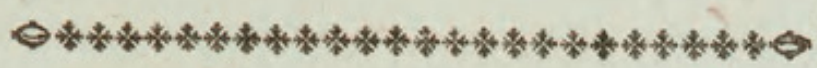

\section{CHARACTER GENERICUS.}

Rostrum conicum, rectum, acuminatum.

Lin. Syst. Nat. p. $31 \%$.

CHARACTER SPECIFICUS, Ec.

FRINGILLA olivacea, fronte gula caudaque rubris, abdomine albo nigroque undulato.

FRINGILLA supra viridis, collo cinereo, pectore flavo, capistro gula uropygio caudaque rubris, abdomine maculis lunatis albis.

Lath. ind. orn. p. 441.

\section{FRINGILLA ELEGANS.}

Lin. Syst. Nat. Gmel. p. 912.

Le beau Marquet.

$$
\begin{aligned}
& \text { Buff. ois. 3. p. } 497 \\
& \text { Pl. Enl. 203. f. } 1 .
\end{aligned}
$$

Africam incolit pulcherrima hæc avis, cujus magnitudinem veram ostendit tabula. 




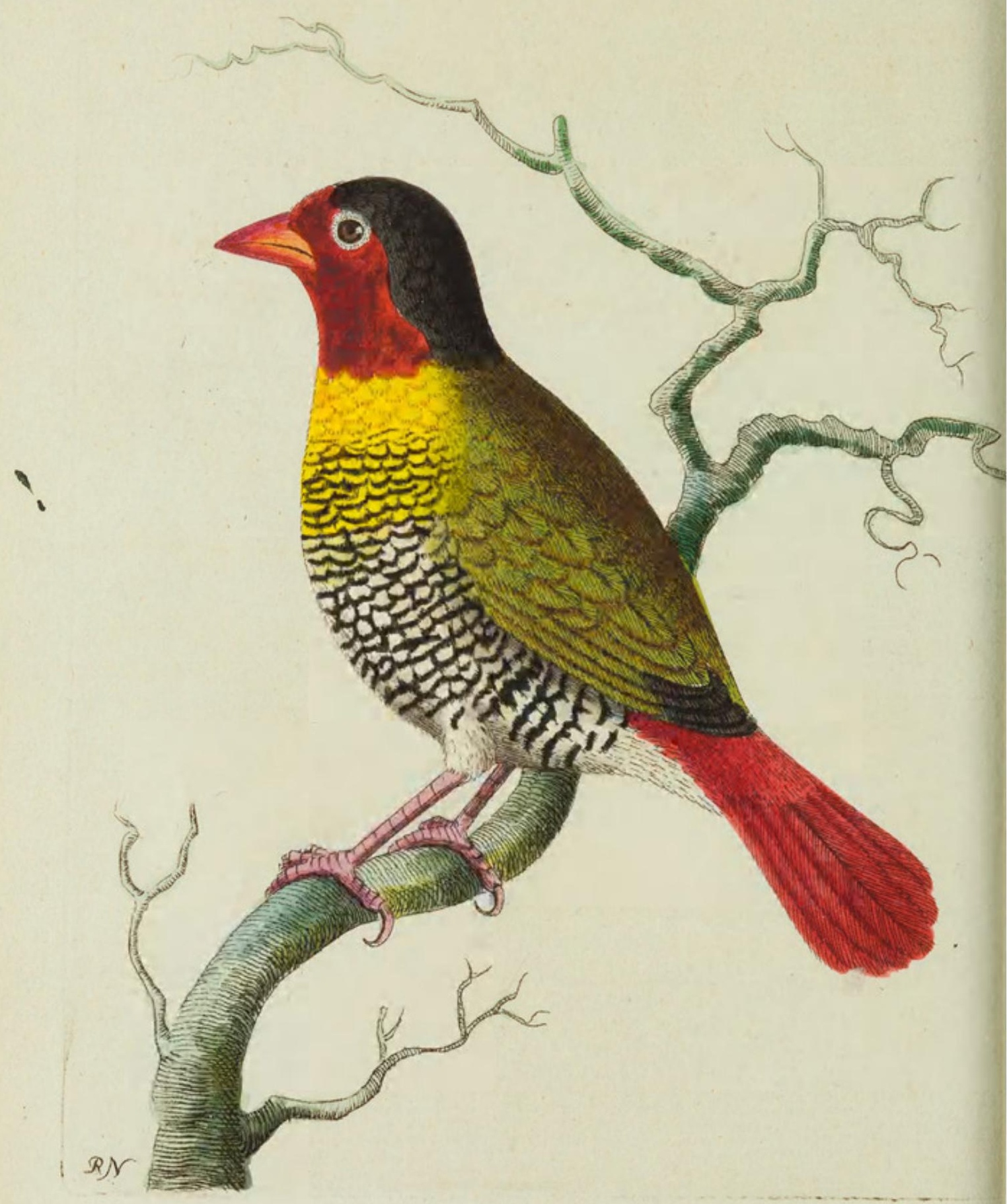




\section{THE \\ VARIEGATED FINCH.

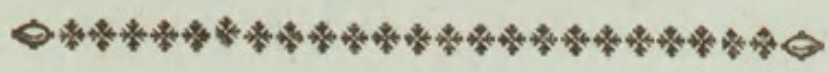

GENERIC CHARACTER。

Bill conic, strait, sharp-pointed.

\section{SPECIFIC CHARACTER, EृC.}

Olive-green FINCH, with red front, throat and tail, and abdomen variegated with black and white.

\section{Elegant FINCH.}

Lath. syn. 3. p. 266 .

This highly beautiful species is a native of Africa, and is represented on the annexed plate in its natural size. 


\section{$2 \mathrm{BHL}$ Biodiversity Heritage Library}

Shaw, George. 1802. "The Variegated Finch, Fringilla elegans [PI. 505]." The Naturalist's Miscellany 13(CLVI), https://doi.org/10.5962/p.310951.

View This Item Online: https://www.biodiversitylibrary.org/item/281546

DOI: https://doi.org/10.5962/p.310951

Permalink: https://www.biodiversitylibrary.org/partpdf/310951

\section{Holding Institution}

Museums Victoria

\section{Sponsored by}

Atlas of Living Australia

\section{Copyright \& Reuse}

Copyright Status: Public domain. The BHL considers that this work is no longer under copyright protection.

This document was created from content at the Biodiversity Heritage Library, the world's largest open access digital library for biodiversity literature and archives. Visit BHL at https://www.biodiversitylibrary.org. 